\title{
Perception of the hedonic value of residences in the neighborhood of Three Green Urban Parks
}

The objective of this article was to examine how users and residents of three urban parks in Campo Grande, MS, Brazil, perceive their existence, degree of satisfaction and attitudes in preserving them. A quantitative approach was employed in 412 users of the three Parks. Information on its sociodemographic characteristics, satisfaction with the park and environmental preservation attitude was collected, employing a seven-point Likert scale. The data collected revealed that the general satisfaction with the park contributes to the hedonic perception of the increase in the property value. From the factor variance analysis, overall satisfaction, preservationist attitude and park location showed significant relationships, such as interactions in the increase in the property value. It is noteworthy that there are differences in the perception of the satisfaction of residents close to the three parks. This article presents some interesting relationships under the aspects of theoretical implication, such as the contribution to studies on the City Parks and their relations with users and residents around them.

Keywords: Environmental Amenities; Factor Variance Analysis; Environmental Behavior; Environmental Perception; Hedonic Valuation.

\section{Percepção do valor hedônico de residências na vizinhança de Três Parques Verde Urbanos}

\begin{abstract}
O objetivo deste do artigo foi examinar como os usuários e moradores vizinhos de três Parques Urbanos, em Campo Grande, MS, percebem a sua existência, o grau de satisfação e as atitudes na preservação desses. Empregou-se uma abordagem quantitativa, em 412 usuários dos três Parques. Foram coletadas as informações sobre as suas características sociodemográfica, satisfação com o parque e atitude preservação ambiental, empregando uma escala de Likert de sete pontos. Os dados coletados revelaram que a satisfação geral, com o parque, contribui como a percepção hedônica do aumento do valor do imóvel. Da análise de variância fatorial, a satisfação geral, a atitude preservacionista e o local do parque demonstraram relações significativas, como interações no acréscimo do valor do imóvel. Destaca-se que existem diferenças na percepção da satisfação dos moradores residentes próximos aos três parques. Este artigo apresenta algumas relações interessantes sob os aspectos de implicação teórica, como a contribuição aos estudos sobre os Parques Urbanos e suas relações com os usuários e moradores ao seu redor.
\end{abstract}

Palavras-chave: Amenidades Ambientais; Análise de Variância Fatorial; Comportamento Ambiental; Percepção Ambiental; Valoração Hedônica.

Topic: Desenvolvimento, Sustentabilidade e Meio Ambiente

Reviewed anonymously in the process of blind peer.
Received: 05/10/2020

Approved: 26/11/2020
José Francisco dos Reis Neto (iD

Universidade Anhanguera, Brasil

http://lattes.cnpq.br/9069806202978279

http://orcid.org/0000-0002-1152-1149

jfreisneto@terra.com.br

Michelle da Rosa Lopes

Universidade Anhanguera, Brasil

http://lattes.cnpq.br/4009157582818338

http://orcid.org/0000-0001-9851-2300

michelle.rosa@anhanguera.com

Pablo Antonio Muñoz Gallego (it)

Universidad de Salamanca, Brasil

http://lattes.cnpq.br/3958610916314802

http://orcid.org/0000-0003-4531-2051

pmunoz@usal.es

\author{
Celso Correia de Souza \\ Universidade Anhanguera, Brasil \\ http://lattes.cnpq.br/2881392515816773 \\ http://orcid.org/0000-0002-2689-8264 \\ csouza939@gmail.com \\ Taner Douglas Alves Bitencourt \\ Universidade Anhanguera, Brasil \\ http://lattes.cnpq.br/1157005087372969 \\ http://orcid.org/0000-0002-1501-8567 \\ taner.biteincourt@kroton.com.br
}

Referencing this:

REIS NETO, J. F.; LOPES, M. R.; GALLEGO, P. A. M.; SOUZA, C. C.; BITENCOURT, T. D. A.. Perception of the hedonic value of residences in the neighborhood of Three Green Urban Parks. Revista Ibero Americana de Ciências Ambientais, v.11, n.6, p.600-611, 2020. DOI: http://doi.org/10.6008/CBPC2179-6858.2020.006.0048 


\section{INTRODUCTION}

Environmental resources receive economic value granted by society, even if it does not use it at the moment or expects to use it in the future, in order to preserve flora and fauna, minimize environmental degradation and quality of life (RIERA et al., 2011). Society provides value for the use of the natural good. The valuation of certain environmental characteristics by society, as a revealed preference, influences the value of the housing estate, considering the perceptions of other surrounding assets, such as: landscape, air quality, acoustics, leisure facilities, historical heritage, contemplation of flora and fauna, among others. The property hedonistic value is a characteristic perceived by the revealed characteristics of the environmental amenities, in its surroundings, with addition or reduction of the property's venal value (CHAMP et al., 2003).

The hedonistic valuation takes on greater importance and visualization when the environmental assets are estimated, natural resources that need preservation, and often, are in a state of scarcity or extinction. Castro (2015) presents that hedonistic value is based on the identification of environmental characteristics that can be related to the market price of a good. According to Santarlacci (2013), the hedonic value contributes to the identification of complementary characteristics, existing in a private good, surrounded by environmental amenities, implying or not in the value of property near a green park.

Identifying the society perception for environmental goods is fundamental in the hedonic value construction. Reinke (2013) explains about this concept, indicating its importance of understanding how society perceives green areas, parks, forests, environmental reserves, through the media or in a direct way, both help in better environmental and cultural valuation.

Perception perceives how everyone observes and feels what is around them. It is proven by psychology that other people, or groups of people, can influence the way in which each individual understands the natural environment, emphasizing that the amount of information about environmental amenities, stimulates the senses, sensations, intuitions, reflecting in their perceptions of environmental amenities (MARIN, 2008).

Priego et al. (2008), explain that people exposed to nature are more aware of the environment than those who are away from it, and that socioeconomic status causes choices and preferences for housing close to urban spaces with green areas or urban parks. Urban green spaces or urban parks include different types of active and passive recreational areas with vegetation, street vegetation and pockets of remaining natural vegetation, provide services from individuals to larger social groups and to the entire ecosystem in general (BRUSH et al., 2000).

Urban parks are important means of social interaction. Often, adequate preservation, benefits the well-being to the population and generates positive impact to those living in its surroundings, increasing the perception of the quality of life of the users and visitors of the parks, contributing to the preservation of the fauna and flora that exists in the region. This is also evidenced by Castro (2015) as a way of promoting leisure activities and helping to control air pollution, the preservation of springs and the appreciation of properties nearby. 
The existence of urban parks fulfills unique environmental functions, reinforcing the need for their existence, such as: acoustic isolation - since some gardens function as an acoustic screen between traffic roads and residential areas; the individual and plants' collective esthetics and their landscape, with unbreakable value; scenario of many recreational activities. These services and many others offered by urban green areas explain the influence of environmental variables on housing prices (LUTTIK, 2000). Morancho (2003) complements the existence of ways to capture the value of environmental assets in monetary units, a value that is sometimes obtained indirectly by people's behavior, using the travel cost method, or the contingent assessment method, investigating directly to people how much they would be willing to pay for their use or conservation. Gundmeda (2005) corroborates, the housing prices, show how much people are willing to pay for amenities in a pleasant location.

The choice for a dwelling is linked to three primordial vectors: physical and structural characteristics of the property; composition of its locality, easy access and neighboring; and, environmental characteristics inherent to the property (squares, parks, wooded sites, etc.) (ARRAES et al., 2008).

Gundmeda (2005) and Freeman et al. (2014) state that the residences satisfy a class of products that the population distinguish them from three characteristics, such as: structural ( $\mathrm{m}^{2}$ built; common areas; number of rooms, bathrooms and other rooms; garages; age of the property; gardens; type of residence); Implementation of public policies (type of neighborhood: trading; schools; shopping centers; health centers; police; security tour; urban bus lines; criminality; accessibility to access roads); and environmental Quality (environmental areas adjacent to the property: air and water quality; noise; proximity to green areas; parks; river; lake or sea). For Santarlacci (2013), the green areas and urban parks are places of total social interaction, amplifying the human conviviality among individuals, and the interactions with the environment, which are primordial in the current climate of contemporary life.

Gomes (2014), explains that urban parks have a large territorial extension (at least one block), are generally open to the public, have natural green areas, attracting endemic and exotic fauna, some with water springs, house in an organized way: walking track, sports venues, playgrounds, and contemplation to the environment.

Castro (2015) presents in his study three interesting cases about hedonic value and environmental amenities and reported in the sequence. The study by Gibbons et al. (2014), in real estates in England, indicated that the nearby parks with environmental amenities presented hedonistic values of almost $5 \%$ over the value of venal and that, every kilometer away from the park, the value decreased by $0.4 \%$. Research carried out in Austria by Herath et al. (2014) indicated that the buildings decreased by up to $0.15 \%$ when they moved away from the green belt, with microclimate control features and environmental amenities offerings. For the Cebula (2009) study, real estate prices in a historic American city increase by up to $17 \%$ when the residence is close to parks, lakes or squares.

For the case of Campo Grande, the article studied the residents' perceptions in the vicinity of the parks: Ayrton Senna; Matas do Segredo and Nações Indígenas, located in three distinct regions, taking into account the existing environmental attributes in their regions, satisfaction at the place of residence, 
conviviality with the parks, their conservative attitudes, and value economically the residents' perceptions regarding their properties.

From the previous discussions, regarding the perceptions of the existence of the Urban Green Parks, relating the conservationist attitudes and the satisfaction of the existence, use of the equipment, conviviality with the flora and fauna, by the users who live close to them, suggest the following hypotheses: $\mathrm{H}$ : Regarding the Increase in the Value of the Real Estate (H1a), General Satisfaction (H1b) and the Preservationist Attitude (H1c), the perceptions are different for each of the City Parks; H2: The interactions of General satisfaction ( $\mathrm{H} 2 \mathrm{a}$ ) and Preservationist Attitude ( $\mathrm{H} 2 \mathrm{~b})$, in relation to the Parks, influence the perception of the increase in value of the Real Estate; H3: The main effects of the General satisfaction (H3a) and Preservationist Attitude ( $\mathrm{H} 3 \mathrm{~b})$, in relation to the Parks, influence in the perception of the increase in value of the Real Estate.

\section{METHODOLOGY}

In order to meet the objectives of this Article, a quantitative approach was used, with representative samples of the population of Campo Grande, of those who know and attend the three Parks under study. A theoretical and published reference survey was carried out in order to know what has already been studied on the subject. Data collection was carried out, under control conditions and with people around the Parks who were willing to participate, considered as a group of interest, using structured procedures and a formal questionnaire for data collection. There was no identification of the respondent, guaranteeing his or her secrecy, and the data were processed in numerical sets through statistical procedures.

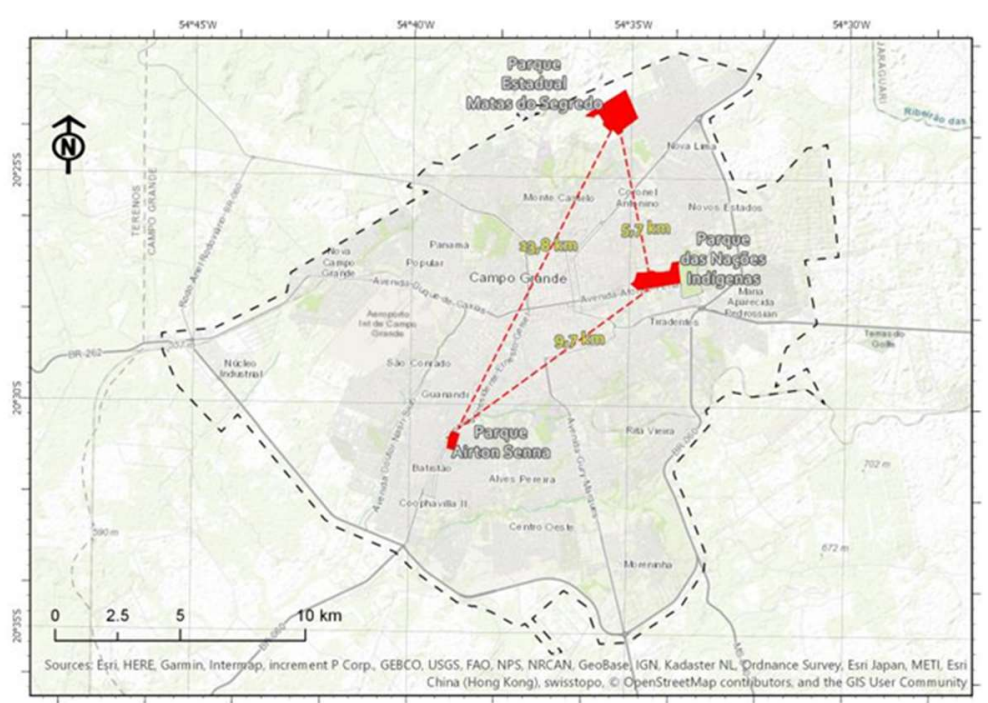

Figure 1: Location of the three Parks researched in the City of Campo Grande, MS and their respective distances between them. Source: PLANURB - Instituto Municipal de Planejamento Urbano - Campo Grande, MS.

The target population was made up of the individuals who attended the research objects (Figure 1): Parque das Nações Indígenas (PNI), located in the central region of the city; Ayrton Senna Park (PAS) , located in the southeast region of the city; and the Parque Matas do Segredo (PMS) in the northern region.

The structured questionnaire was considered the Adams et al. (2003) proposal, emphasizing the groups of sociodemographic variables, general satisfaction with the park, conservation attitude and the 
typing of the interviewee to his or her vision of park use. A pre-test was performed with a small number of $\mathrm{PNI}$ users to verify that the questionnaire was logical and unambiguous. The questionnaires were then applied around the three Parks, from 04/16/2018 to 06/08/2018. The face-to-face interviews were administered by trained, accredited researchers to the people who were willing to do so, constituting a sample for non-probabilistic convenience.

The total sample, for the three Parks objects of the study, was 824 interviewees, with 412 individuals who identified attending the Parks and living close to them.

The data quantitative analyzes were performed using SPSS v.25. Data exploratory analysis was performed for the verification of the atypical data and missing values. Tests were performed to verify linearity assumptions (Pearson's linear correlation analysis and dispersion diagram among variables: The relationship between two variables should be linear), normality (Shapiro-Wilk's test: Each variable should be normally distributed) and homoscedasticity (Kolmogorov/Sminvov's test: conditional to the explanatory variables, the error variance is constant) of the independent variables according to the recommendations proposed by (HAIR JUNIOR et al., 2009). The of results of the tests indicated the assumptions fulfillment and the nonobservation of atypical data. As a measure of internal reliability, or of the degree of consistency between multiple measurements of a latent variable, Cronbach's alpha was used, adopting the lower limit of 0.70 . For the variable General satisfaction, Cronbach's alphas were greater than 0.91 for each of the Park.

For de decision on to accept, or not, the proposed hypotheses, the statistical procedure of the Analysis of Variance (ANOVA) factorial was used, considering the dependent variable the increase of the Value of the Property, in percentage, and the independent variables, or fixed factors, the one-dimensional values of General satisfaction and Preservationist Attitude (PALLANT, 2016).

These two variables, General satisfaction and Preservationist Attitude, were adjusted in new scales with three categories to process the factorial ANOVA. The variable General Satisfaction, measured by metric scale from 1 to 7, was divided into three categories using quartile values, with the new denomination: Low (<4.3), Neutral (between 4.3 to 6.1) and High (> 6.1). The Preservationist Attitude variable, measured by a 5point Likert scale, was modified to a 3-category scale called: Negative (sum of scales $1=$ totally against and $2=$ partly against), neutral ( $3=$ scale either for or against) and positive (sum of scales $4=$ partially in favor and $5=$ totally in favor).

\section{RESULTS AND DISCUSSION}

For the users of the three Parks that were interviewed, the predominance is of women (51.9\%), with higher education (47.1\%) and family income between $\mathrm{R} \$ 1.001$ and $\mathrm{R} \$ 3,000$ (44.7\%). Other sociodemographic characteristics for each of the Parks are shown in Table 1.

Table 1: Sociodemographic characteristics of interviewees who reported living near the three City Green Parks ( $n=412$ ).

\begin{tabular}{|c|c|c|c|c|c|c|c|c|c|}
\hline \multirow[b]{3}{*}{ Variable } & & \multicolumn{8}{|c|}{ Urban Green Parks } \\
\hline & & \multicolumn{2}{|c|}{ Nações Indígenas } & \multicolumn{2}{|c|}{ Ayrton Senna } & \multicolumn{2}{|c|}{ Matas do Segredo } & \multicolumn{2}{|c|}{ Total } \\
\hline & & $\mathrm{n}$ & $\%$ & $\mathrm{n}$ & $\%$ & $\mathrm{n}$ & $\%$ & & $\%$ \\
\hline & Male & 98 & 49.0 & 43 & 41.3 & 57 & 52.8 & 198 & 48.1 \\
\hline
\end{tabular}




\begin{tabular}{|c|c|c|c|c|c|c|c|c|c|}
\hline & Female & 102 & 51.0 & 61 & 58.7 & 51 & 47.2 & 214 & 51.9 \\
\hline \multirow[t]{4}{*}{ Age Range } & Up to 24 & 58 & 29.0 & 29 & 27.9 & 16 & 14.8 & 103 & 25.0 \\
\hline & 25 to 34 & 53 & 26.5 & 28 & 26.9 & 29 & 26.9 & 110 & 26.7 \\
\hline & 35 to 44 & 59 & 29.5 & 15 & 14.4 & 28 & 25.9 & 102 & 24.8 \\
\hline & Over 45 & 30 & 15.0 & 32 & 30.8 & 35 & 32.4 & 97 & 23.5 \\
\hline \multirow[t]{3}{*}{ Schooling } & Elementary & 15 & 7.5 & 18 & 17.3 & 10 & 9.3 & 43 & 10.4 \\
\hline & Medium & 78 & 39.0 & 38 & 36.5 & 59 & 54.6 & 175 & 42.5 \\
\hline & Upper & 107 & 53.5 & 48 & 46.2 & 39 & 36.1 & 194 & 47.1 \\
\hline \multirow[t]{4}{*}{ Family income } & Up to $R \$ 1000$ & 31 & 15.5 & 9 & 8.7 & 22 & 20.4 & 62 & 15.0 \\
\hline & From $\mathrm{R} \$ 1001$ to $\mathrm{R} \$ 3000$ & 76 & 38.0 & 49 & 47.1 & 59 & 54.6 & 184 & 44.7 \\
\hline & From $\mathrm{R} \$ 3001$ to $\mathrm{R} \$ 5000$ & 39 & 19.5 & 27 & 26.0 & 16 & 14.8 & 82 & 19.9 \\
\hline & Over $\mathrm{R} \$ 5000$ & 54 & 27.0 & 19 & 18.3 & 11 & 10.2 & 84 & 20.4 \\
\hline
\end{tabular}

Table 2 provides the descriptive statistics values for each of the Parks and Total, for the independent variables General Satisfaction and its observed items, and for the Preservationist attitude.

Table 2: Average and standard deviation of the latent variables and observed items for the three Parks and Total in 2018.

\begin{tabular}{|c|c|c|c|c|c|c|c|c|}
\hline \multirow[b]{3}{*}{ Variable } & \multicolumn{8}{|c|}{ Urban Green Parks } \\
\hline & \multicolumn{2}{|c|}{ Nações Indígenas $(n=200)$} & \multicolumn{2}{|c|}{ Ayrton Senna $(n=104)$} & \multicolumn{2}{|c|}{$\begin{array}{l}\text { Matas do Segredo } \\
(n=108)\end{array}$} & \multicolumn{2}{|c|}{$\begin{array}{l}\text { Total } \\
(n=412)\end{array}$} \\
\hline & $\mathrm{m}$ & $\mathrm{dp}$ & $\mathrm{m}$ & $\mathrm{dp}$ & $\mathrm{m}$ & $\mathrm{dp}$ & $\mathrm{m}$ & $\mathrm{dp}$ \\
\hline General Satisfaction & 5.8 & 1.1 & 5.2 & 1.1 & 5.1 & 1.1 & 5.5 & 1.1 \\
\hline Satisfaction in living near the park & 5.8 & 1.8 & 5.4 & 1.7 & 5.6 & 1.3 & 5.7 & 1.7 \\
\hline Place for social conviviality. & 6.0 & 1.4 & 5.6 & 1.4 & 5.1 & 1.6 & 5.7 & 1.5 \\
\hline Appearance & 6.0 & 1.4 & 5.3 & 1.4 & 5.1 & 1.5 & 5.6 & 1.5 \\
\hline Attractiveness & 5.9 & 1.4 & 5.1 & 1.4 & 5.0 & 1.5 & 5.5 & 1.5 \\
\hline Quiet & 6.0 & 1.4 & 5.2 & 1.5 & 5.4 & 1.3 & 5.6 & 1.5 \\
\hline Cozy & 6.0 & 1.3 & 5.0 & 1.5 & 5.2 & 1.5 & 5.5 & 1.5 \\
\hline Beautiful & 6.1 & 1.4 & 5.1 & 1.5 & 5.1 & 1.5 & 5.6 & 1.5 \\
\hline Clean & 5.5 & 1.9 & 5.1 & 1.5 & 5.1 & 1.7 & 5.3 & 1.7 \\
\hline Vegetation. & 6.0 & 1.5 & 5.3 & 1.5 & 5.5 & 1.4 & 5.7 & 1.5 \\
\hline Maintenance & 4.1 & 2.2 & 4.7 & 1.6 & 4.8 & 2.0 & 4.4 & 2.0 \\
\hline Lighting & 4.9 & 2.0 & 5.1 & 1.6 & 4.8 & 1.6 & 4.9 & 1.8 \\
\hline Location & 6.1 & 1.5 & 5.4 & 1.3 & 5.4 & 1.4 & 5.8 & 1.4 \\
\hline Presence of several animals. & 6.4 & 1.2 & 4.6 & 1.9 & 5.5 & 1.4 & 5.7 & 1.7 \\
\hline Place for sports practices & 6.1 & 1.4 & 5.7 & 1.3 & 4.3 & 2.0 & 5.5 & 1.7 \\
\hline Preservationist Attitude & 4.4 & 1.0 & 4.3 & 1.0 & 4.4 & 0.8 & 4.4 & 1.0 \\
\hline
\end{tabular}

Legend: $n=$ size of sample; $m$ - average; $d p$ - standard deviation.

It was intended to verify whether there are significant differences at $p<0.05$ among the means of the one-dimensional variables in each of the Parks studied. Table 3 provides us the $t$ test results for the independent samples.

Table 3: Means and standard deviation values as measurements for the statistical test of independent samples for each of the three Parks.

\begin{tabular}{lllllllll}
\hline & \multicolumn{2}{l}{ Urban Green Parks } & \multicolumn{1}{l}{} \\
\cline { 2 - 11 } Variable & \multicolumn{2}{l}{ Nações Indígenas } & \multicolumn{2}{l}{ Ayrton Senna } & \multicolumn{2}{l}{ Matas do Segredo } & Total \\
\cline { 2 - 11 } & $\mathrm{m}$ & $\mathrm{dp}$ & $\mathrm{m}$ & $\mathrm{dp}$ & $\mathrm{m}$ & $\mathrm{dp}$ & $\mathrm{m}$ & $\mathrm{dp}$ \\
\hline Addition to the Property value & $38,4_{\mathrm{a}}$ & 21.6 & $32,1_{\mathrm{a}}$ & 29.6 & $23.9_{\mathrm{b}}$ & 21.9 & 33.0 & 24.7 \\
\hline General Satisfaction & $5.8_{\mathrm{a}}$ & 1.1 & $5.2_{\mathrm{b}}$ & 1.1 & $5.1_{\mathrm{b}}$ & 1.1 & 5.5 & 1.1 \\
Preservationist Attitude & $4,4_{\mathrm{a}}$ & 1.0 & $4,3_{\mathrm{a}}$ & 1.0 & $4,4_{\mathrm{a}}$ & 0.8 & 4.4 & 1.0 \\
\hline
\end{tabular}

Legend: $\mathrm{n}=$ size of sample; $\mathrm{m}$ - average; $\mathrm{dp}$ - standard deviation.

Note: the values in the same row that do not share the same subscript are quite different in $p<0.05$ in the equality test for column averages.

For the addition in the Value of the Property, there are no significant differences at $p<0.05$, in the perception of residents in the vicinity of the Parks Nações Indígenas and Ayrton Senna. Whereas for the residents in the vicinity of Matas do Segredo Park, these reported the lower perception of the increase in the 
value of the property, compared to the other two previous ones.

It is observed that with the growth of the population of Campo Grande, the search for houses increases, seeking to aggregate new factors such as: natural landscapes in urban areas, urban parks and other green spaces. The population seeks well-being, for example, by seeking a set of ecosystem services, including noise and pollution reduction and better microclimate (ANDREWS et al., 2017). According to Barbieri (2004), environmental perception is a matter of consciousness, influenced by the benefits and perception of the well provided with the maintenance of the green areas. In such a perspective, Gundmeda (2005) shows that the prices of urban buildings suffer from influences of hedonistic perception, when the resident is willing to value his or her property to the sites with pleasant, social aspects and environmental interaction.

General satisfaction is reported as the greatest by the users of Nações Indígenas Park, with no significant difference at $p<0.05$ for those users of the Ayrton Senna and Matas do Segredo Parks. It is inferred that the users of the Nações Indígenas Park are satisfied with what the Park offers in terms of equipment, flora, fauna and maintenance, a little higher than what was observed for the users of Aytron Senna and Matas do Segredo Parks. It is noteworthy that the Nações Indígena Park is located in a noble region of the city and has a higher concentration of available infrastructure, and another memorable item is the place to be referred to as the city's postal card. Salazar et al. (2007), complement that the smaller the distance from urban parks' homes, the greater the identification of perceived satisfaction, when this proximity is associated with higher quality of property this satisfaction increases.

For the Preservationist Attitude, there are no significant differences at $p<0.05$ among the three Parks, indicating that these users and residents in the vicinity are in favor of the existence of protected environmental preservation areas within Campo Grande. This result can be explained that these users and residents in the vicinity of the three Parks have feelings and values underlying the behavior of preserving the environmental amenities very close, with no conflict between them. They all consider that protecting natural areas and making them an indispensable space for their surroundings is relevant. It is inferred thus that society recognizes the existence of the Parks in the same way as an alliance with nature. It can be complementary that there are no identified conflicts of economic, social and political order, due to the existence of Parks in urban areas and protected by law (BRITO, 2008). Thus, it was inferred that hypotheses $\mathrm{H} 1 \mathrm{a}$ and $\mathrm{H} 1 \mathrm{~b}$ are accepted in part and $\mathrm{H} 1 \mathrm{c}$ is rejected.

Factorial ANOVA was performed to explore the impact of General Satisfaction and Preservationist Attitude on the perception of the increase in the value of the Real Estate. The Levene's test of variance equality presented values of $p<0.001$, indicating the violation of the null hypothesis, that is, there is no homogeneity of variance of the increase of the value of the Property in the Parks. Leech et al. (2015) mention that SPSS v.25 software uses an algorithm to calculate ANOVA regression that decreases this problem; however, attention should be given regarding the choice of post hoc tests.

Table 4 provides the descriptive statistics for each subgroup considered in the analysis, indicating the interactions of the independent variables, General Satisfaction and Preservationist Attitude, on the dependent variable Increase in the Value of the Property. 
Table 4: Means, standard deviation and size of the sample for the Increase in the Value of the Property considering the Preservationist Attitude as a function of the General satisfaction and the Park.

\begin{tabular}{|c|c|c|c|c|c|c|c|c|c|c|c|c|}
\hline \multirow[b]{3}{*}{ Preservationist Attitude } & \multicolumn{12}{|c|}{ General Satisfaction } \\
\hline & \multicolumn{3}{|l|}{ Low } & \multicolumn{3}{|c|}{ Neutral } & \multicolumn{3}{|l|}{ High } & \multicolumn{3}{|l|}{ Total } \\
\hline & $\mathrm{m}$ & $\mathrm{dp}$ & $\mathrm{n}$ & $\mathrm{m}$ & $\mathrm{dp}$ & $\mathrm{n}$ & $\mathrm{m}$ & $\mathrm{dp}$ & $\mathrm{n}$ & $\mathrm{m}$ & $\mathrm{dp}$ & $\mathrm{n}$ \\
\hline \multicolumn{13}{|c|}{ Park Nações Indígenas $(n=200)$} \\
\hline Negative & 48.7 & 15.9 & 8 & 31.2 & 11.8 & 4 & 13.0 & 0.0 & 2 & 38.6 & 18.7 & 14 \\
\hline Neutral & 45.0 & 8.7 & 3 & 22.1 & 9.0 & 7 & 29.0 & 24.8 & 11 & 29.0 & 19.9 & 21 \\
\hline Positive & 29.6 & 10.1 & 8 & 40.3 & 20.0 & 85 & 39.6 & 24.7 & 72 & 39.5 & 21.9 & 165 \\
\hline Total & 40.1 & 15.3 & 19 & 38.7 & 19.7 & 96 & 37.7 & 24.8 & 85 & 38.4 & 21.7 & 200 \\
\hline \multicolumn{13}{|l|}{ Ayrton Senna Park $(n=104)$} \\
\hline Negative & - & - & 0 & 11.6 & 2.8 & 3 & 25.0 & 0.0 & 1 & 15.0 & 7.1 & 4 \\
\hline Neutral & 8.3 & 2.8 & 3 & 42.6 & 53.0 & 12 & 42.0 & 21.3 & 10 & 38.3 & 39.9 & 25 \\
\hline Positive & 24.3 & 13.3 & 22 & 24.7 & 19.6 & 42 & 67.4 & 36.0 & 11 & 30.9 & 25.9 & 75 \\
\hline Total & 22.4 & 13.5 & 25 & 27.8 & 30.1 & 57 & 53.9 & 31.9 & 22 & 32.1 & 29.6 & 104 \\
\hline \multicolumn{13}{|c|}{ Matas do Segredo Park $(n=108)$} \\
\hline Negative & 24.0 & 0.0 & 1 & 50.0 & 0.0 & 1 & 10.0 & 0.0 & 3 & 28.8 & 17.4 & 5 \\
\hline Neutral & 11.6 & 7.6 & 3 & 16.2 & 10.3 & 4 & - & - & 0 & 14.3 & 8.8 & 7 \\
\hline Positive & 15.9 & 10.4 & 21 & 25.1 & 21.2 & 59 & 34.8 & 34.0 & 16 & 24.8 & 22.7 & 96 \\
\hline Total & 15.8 & 10.0 & 25 & 25.0 & 20.9 & 64 & 30.9 & 32.4 & 19 & 23.9 & 21.9 & 108 \\
\hline
\end{tabular}

Legend: $\mathrm{m}$ =means; $\mathrm{dp}$ - standard deviation; $\mathrm{n}=$ size of sample.

The results of factorial ANOVA regression, direct effects and interactions of the categorical independent variables on the dependent variable are presented in Table 5.

When there is interaction, the effect of an independent variable on one dependent variable varies according to the values of the other independent variable. If the probability of $\mathrm{F}$ is lower than 0.05 , for any combination, it is concluded that this combination interaction affects the dependent variable. Note that the concept of interaction between two independent variables is not related to the question of whether the two variables are correlated.

Of the interactions calculated, $P \times A$ is not significant, with $F(4.387)=0.775, p=0.542$, indicating that there are no significant differences in the Preservationist Effect on the increase in Value in the Property for the Parks. For the P XS interaction, it is statistically significant, $F(4.387)=3.463, p=0.009$, which indicates that the effect of General satisfaction on the increase in the Value of the Property depends on the Park in question. Interactions $\mathrm{S} \times \mathrm{A}, \mathrm{F}(4.387)=2.521, \mathrm{p}=0.041$, and $\mathrm{P} \times \mathrm{S} \times \mathrm{A}, \mathrm{F}(6.387)=2.382, \mathrm{p}=0.028$ are also significant.

Table 5: Results of Variance Analysis for the Main Effects and Interactions among Parks, General satisfaction and Preservationist Attitude on the increase in the Value of the Property

\begin{tabular}{llllll}
\hline Variable & $\mathrm{gl}$ & Average Squares & $\mathrm{F}$ & $\mathrm{p}$ & $\eta^{2}$ \\
\hline Park (P) & 2 & 856.2 & 1.651 & 0.193 & 0.008 \\
General Satisfaction (S) & 2 & 298.1 & 0.575 & 0.563 & 0.003 \\
Preservationist Attitude (A) & 2 & 1497.3 & 2.887 & 0.057 & 0.015 \\
P x S & 4 & 1795.9 & 3.463 & 0.009 & 0.035 \\
P x A & 4 & 402.2 & 0.775 & 0.542 & 0.008 \\
S X A & 4 & 1307.7 & 2.521 & 0.041 & 0.025 \\
P x S X A & 6 & 1235.4 & 2.382 & 0.028 & 0.036 \\
Error & 387 & 518.7 & & & \\
\hline
\end{tabular}

Note: $R^{2}=0.197 ; R^{2}$ adjusted $=0.147$

Legend: $g$ l - degree of freedom; F - ratio F; $p$ - significance level; $\eta^{2}$ - partial eta to the square (Size effect).

The indication of the absence of the effect of Conservationist Attitude interaction on the increase in the Value of the Property, comes from previous comments that for the three Parks there was the same perception. According to Oliveira (2001), the environmental attitude is a differential of the human being with 
awareness, affectivity and critical knowledge in the geographical scope, understanding that the consequences, in case the natural resource ceases to exist, causes irreparable externalities of a cultural and non-economic character. This relationship can change the emotion intensity, $\mathrm{o}$ it can be related to what is expected to be achieved and what is achieved from the amenities environment.

General satisfaction is an indication of the logic of the activities and attributes offered by the Parks. The traditional functions of an urban park (ecology, environment, leisure and esthetics) are assessed by considering the spatial layout, service provision and infrastructure (LEITE et al., 2018). Thus, it is inferred that the greater the perception of the user with the General Satisfaction with the Park, the greater his or her perception will be in the hedonistic valuation of his or her property.

Tavares et al. (2010) corroborates that positive and negative externalities identify nearby, and urban parks define the resident's satisfaction, mainly related to maintenance, safety and well-being present in the parks. Possibly, the existence of greater interaction with the public bodies and the maintenance of the Nações Indígenas Park add greater significance to the inhabitants of this park in relation to the other parks under study. The aspects analyzed here allow the H2a hypothesis to be accepted and the H2b hypothesis rejected.

In relation to the main effects of General Satisfaction and Preservationist attitude on the increase in the Value of the Property, with the data presented in Table 5, both are not significant at $p<0.05$. Here, the main effects are understood as the unique effects of the independent categorical factors. If the probability of $\mathrm{F}$ is lower than 0.05 , for any independent categoric variable, it is concluded that this affects the dependent variable. This leads to infer that the General Satisfaction and Preservationist Attitude do not produce direct effects or differ in categorical terms in the Increase of the Property Value, in each Park.

Analyzing the data of the means and total standard deviations, presented in Table 4, for each group of General Satisfaction, Preservationist Attitude and Park, the multiple Post Hoc comparisons were made using the Bonferroni test. For the mean values of the Increase in the Property Value among the categorical subgroups of General Satisfaction, it was indicated that the comparison between the High ( $m=37.7, S D=24.9)$ and the Neutral $(m=38.6, S D=19.7)$, these are significantly different to $p<0.05$, as well as the High in relation to the Low $(m=40.1, S D=15.3)$. There are no differences between Neutral and Low subgroups. Similarly, for the categorical subgroups of the Preservationist Attitude, the multiple comparisons did not indicate significant differences. When multiple comparisons of the Increase in the Value of the Property are made among the Parks, there are significant differences at $p<0.05$ between Nações Indígenas $(m=38.4, S D=21.7)$ and Matas do Segredo $(m=23.9, S D=21.9)$ Parks, between Matas do Segredo and Ayrton Senna $(m=32.1$, $S D=29.6)$. There are no differences between Nações Indígenas and Ayrton Senna Parks.

However, even if there are significant differences among the subgroups, the effect size $\left(\eta^{2}\right)$ was considered, a measure of the relationship size between the groups, to indicate the proportion of variance that the independent variables explain the dependent variable, according to Cohen's criteria presented by Tabachnick et al. (2007) and Cohen et al. (2009). The values obtained are classified as small, and by inferring that the differences among the categorical subgroups of the three variables analyzed seem to be of low 
practical significance. Also, under the view of the adjusted $R 2$ criterion $\left(R^{2}\right.$ adjust $\left.=0.147\right)$, that for Tabachnick et al. (2007), this coefficient of determination relates the multiple correlation coefficient, to the square and adjusted for the number of independent variables, as an indication of the amount of variance that is explained by the General Satisfaction, Preservationist Attitude and the Park in the increase in the Value of the Property, the explanatory value of $14.7 \%$ of the variance was obtained. This value, according to Cohen et al. (2009) is considered as between a small and medium value for applied social science studies. In other words, due to the values obtained from the $\eta^{2}$ and the $R^{2}$ adjust, it was considered that there were no differences in the increase in the value of the Property due to the contribution of each categorical subgroup of General Satisfaction, Preservationist Attitude and Parks.

It is believed that there are no differences among the subgroups of General Satisfaction, Preservationist Attitude and the residents' perception regarding the increase in the value of their properties, confirm the findings of Marin (2008), where it discusses that emotions and bonds created among the residents close to green areas are built by the knowledge between the human being and the environment. They are attracted by individual values and development of the singular perception system, adding that the individuals living in these vicinities are more demanding in information about the vegetation and biome present, and the more they know the more they tend to preserve, thus increasing their satisfaction.

With the above discussion, it is inferred that in the perception of the user and resident near the Park, the unique effects of the categorical independent factors do not affect the increase in the Value of the Propriety. Therefore, it is possible to infer that hypotheses $\mathrm{H} 3 \mathrm{a}, \mathrm{H} 3 \mathrm{~b}$ and $\mathrm{H} 3 \mathrm{~b}$ are rejected.

\section{CONCLUSIONS}

For the users of the three Urban Green Parks, the object of the study, the importance for the composition of the green areas in Campo Grande is evident. In general, the level of satisfaction of living near the Park, understanding how a place of social conviviality and the existence of flora and fauna, are highlighted by the population to the Parks. Nações Indígenas Park, in the central part of Campo Grande, stands out as with greater general satisfaction, in relation to the other two Parks. For Nações Indígenas Park there are greater perceptions for the environmental amenities offered, such as the presence of animals, their location, beautiful environment, calm, cozy, place for sports and social life practices. For the other two Parks, these perceptions are smaller.

The position regarding the Parks preservation, as Preservationist Attitude, is perceived as an intermediary, on a scale of neither against nor in favor, in such a context, it is observed that people, regardless of their socioeconomic position, are more involved in environmental preservation practices, possibly as indicated by Godim (2012), because of the emergence of planet preservation highlighted at the ECO-92 international conference, creating new behaviors with the environment, the emergence of specific legislations, culminating in new attitudes with the preservation and maintenance of natural resources.

It can be inferred that the perception of the increase in the value of the property, under the hedonic perspective, differs in relation to each Park. The greatest perceived value is for those people who live and 
use the Nações Indígenas Park in relation to the other two ones. Finally, what stands out in this study is that the perception of the increase in the value of the property is related to the intensity of the general satisfaction perceived by the users and resident in their neighborhood of the Park.

\section{REFERENCES}

ANDREWS, B.; FERRINI, S.; BATEMAN, I. (2017). Good parksbad parks: the influence of perceptions of location on WTP and preference motives for urban parks. Journal of

Environmental Economics and Policy, v.6, n.2, p.204-224, 2017. DOI:

https://doi.org/10.1080/21606544.2016.1268543

ARRAES, R. A.; SOUSA FILHO, E.. Externalidades e formação de preços no mercado imobiliário urbano brasileiro: um estudo de caso. Economia aplicada, v.12, n. 2, p.289-319, 2008. DOI: http://dx.doi.org/10.1590/S1413$\underline{80502008000200006}$

BARBIERI, J. C.. Gestão ambiental empresarial: conceitos, modelos e instrumentos. São Paulo: Saraiva, 2004.

BRITO, D. M.. Conflitos em unidades de conservação. Revista Eletrônica de Humanidades do Curso de Ciências Sociais, v.1, p.1-12, 2008.

BRUSH, R.; CHENOWETH, R. E.; BARMAN, T.. Group differences in the enjoyability of driving through rural landscapes. Landscape and Urban Planning, v.47, p.39-45, 2000. DOI: http://doi.org/10.1016/S0169-2046(99)00073-0

CASTRO, J. D.. Usos e abusos da valoração econômica do meio ambiente: ensaios sobre aplicações de métodos de função demanda no Brasil. Tese (Doutorado em Economia) Universidade de Brasília, Brasília, 2015.

CEBULA, R. J.. The hedonic pricing model applied to the housing market of the city of Savannah historic landmark district. The Review of Regional Studies, v.1, p.9-22, 2009.

CHAMP, P. A.; BOYLE, K. J.; BROWNS, T. C.. A primer on nonmarket valuation. New York: Springer Science, 2003.

COHEN, J.; COHEN, P.; WEST, S. G.; AIKEN, L. S.. Applied multiple regression/correlation analysis for behavioral sciences (3rd ed.). New York: Routldege, 2009.

FREEMAN, A. M.; HERRIGES, J. A.; KLING, C. L.. The measurement of environmental and resource values: theory and methods. Routledge, 2014.

GIBBONS, S.; MOURATO, S.; RESENDE, G. M.. The amenity value of English nature: a hedonic price approach. Environmental and Resource Economics, v.57, n.2, p.175 196, 2014. DOI: http://doi.org/10.1007/s10640-013-9664-9

GOMES, M. A.. Parques urbanos, políticas públicas e sustentabilidade. Mercator, v.13, n.2, p.79-90, 2014.

GUNDMEDA, H.. Hedonic Price Method: a concept note. Chennai: Madras School of Economics, 2005.
HAIR JUNIOR, J. F.; BLACK, W. C.; BABIN, B. J.; ANDERSON, R. E.; TATHAM, R. L.. Análise multivariada de dados. Porto Alegre: Bookman, 2009.

HERATH, S.; CHOUMERT, J.; MAIER, G.. The value of greebelt in Vienna: a spatial hedonic analysis. Etudes et Documents CERDI, v.2, p.1-36, 2014.

LEECH, N. L.; BARRETT, K. C.; MORGAN, G.. A. IBM SPSS for intermediate statistics: use and interpretation. 5 ed. New York: Routledge, 2015.

LEITE, F. C.; HENZ, A. P.. Parques urbanos de Curitiba (PR): espacialidade, planejamento e turismo. Revista Brasileira de Ecoturismo, v.10, n.4, p.767-788, 2018. DOI: http://doi.org/10.34024/rbecotur.2017.v10.6563

LUTTIK, J.. The value of trees, water and open space as reflected by house prices in The Netherlands. Landsc. Urban Plann, v.48, n.3-4, p.161-167, 2000. DOI: https://doi.org/10.1016/S0169-2046(00)00039-6

MARIN, A. A.. Pesquisa em educação ambiental e percepção ambiental. Revista Pesquisa em Educação Ambiental, São Paulo, v.3, n.1, p.203-222, 2008. DOI: https://doi.org/10.18675/2177-580X.vol3.n1.p203-222

MORANCHO, A. B.. A hedonic valuation of urban green areas. Landscape and urban planning, v.66, n.1, p.35-41, 2003. DOI: http://doi.org/10.1016/S0169-2046(03)00093$\underline{8.36}$

OLIVEIRA, L.. Percepção do meio ambiente e geografia. OLAM Ciência e Tecnologia, Rio Claro, v.1, n.2, p.14-28, 2001.

PALLANT, J.. SPSS survival manual: A step by step guide to data analysis using IBM SPSS (6th ed.). London: McGraw Hill, 2016.

PRIEGO, C.; BREUSTE, J. H.; ROJAS, J.. Perception and value of nature in urban landscapes: a comparative analysis of cities in Germany, Chile and Spain. Landsc Online, v.7, p.122, 2008. DOI: http://doi.org/10.3097/LO.200807

REINKE, A. M. J.. Como perciben el paisaje los habitantes de la ciudad de Xalapa, Veracruz, México. Tese (Mestrado em Ciências) - Inecol - Instituto de Ecologia A.C., Xalapa, 2013.

RIERA, P.. Rentabilidad social de las infraestructuras: las rondas de Barcelona. Madrid: Civitas, 2011.

SALAZAR, D. S.; MENENDEZ, L. G.. Estimating the NonMarket Benefits of an Urban Park: Does Proximity Matter?. Land Use Policy, v.24, n.1, p.296-305, 2007. DOI: http://doi.org/10.1080/19438151003709832 
SANTARLACCI, A.. Externalidades positivas geradas pelo

Parque Olhos D’Água ao mercado imobiliário por meio de índices hedônicos. Dissertação (Mestrado em Ciências Florestais) - Universidade de Brasília, Brasília, 2013.

TABACHNICK, B. G.; FIDELL, L. S.. Using multivariate statistics. 5 ed. Boston: Pearson, 2007.
TAVARES, F. O.; MOREIRA, A. C.; PEREIRA, E. T.. Avaliação imobiliária sob a perspectiva das externalidades: uma revisão da literatura. Revista Universo Contábil, v.6, n.3, p.96-113, 2010.

A CBPC - Companhia Brasileira de Produção Científica (CNPJ: 11.221.422/0001-03) detém os direitos materiais desta publicação. Os direitos referem-se à publicação do trabalho em qualquer parte do mundo, incluindo os direitos às renovações, expansões e disseminações da contribuição, bem como outros direitos subsidiários. Todos os trabalhos publicados eletronicamente poderão posteriormente ser publicados em coletâneas impressas sob coordenação da Sustenere Publishing, da Companhia Brasileira de Produção Científica e seus parceiros autorizados. Os (as) autores (as) preservam os direitos autorais, mas não têm permissão para a publicação da contribuição em outro meio, impresso ou digital, em português ou em tradução. 